\title{
VOLATILITY TRANSMISSION ALONG THE MONEY MARKET YIELD CURVE
}

J. Ayuso, A. G. Haldane and F. Restoy 


\title{
VOLATILITY TRANSMISSION ALONG THE MONEY MARKET YIELD CURVE
}

\author{
J. Ayuso (*), A. G. Haldane (**) \\ and F. Restoy (*)
}

(*) Banco de España.

(**) Bank of England.

This paper was written while Haldane was visiting the Banco de España under the Staff Exchange Programme of the Committee of Governors of the Central Banks of the European Union. The authors are grateful to J. L. Escrivá, F. Gutiérrez, F. Hermann and J. Viñals for helpful discussions and J. J. Pacheco for outstanding research assistance. The views expressed are those of the authors and not necessarily those of the Banco de España or the Bank of England.

Banco de España - Servicio de Estudios

Documento de Trabajo no 9403 
In publishing this series the Banco de España seeks to disseminate studies of interest that will help acquaint readers better with the Spanish economy

The analyses, opinions and findings of these papers represent the views of their authors; they are not necessarily those of the Banco de España.

ISBN: 84-7793-284-0

Depósito legal: M-5315-1994

Imprenta del Banco de España 


\begin{abstract}
In this paper we look to model de volatility of money market interest rates -and the transmission of volatility-along the money market yield curve in four countries: the UK, Germany, France and Spain. We use a conditional variance specification which is based on Nelson's Exponential ARCH. We find a significant volatility transmission effect from overnight to longer term money markets for France, Spain an the UK. We also find that, in our small cross section of countries, those with lower (higher) reserve requirements tend to have higher (lower) interbank interest rate volatility. However, reserve requirements generate a perverse seasonal effect: at the end of the maintenance period, both the level of the overnight interest rate volatility and the magnitude of the transmission effect to the rest of the yield curve are higher.
\end{abstract}





\section{INTRODUCTION}

The debate over optimal monetary policy has often focused on the analysis of volatility tradeoffs associated with different monetary policy schemes. In the early eighties, a number of central banks experimented with monetary control procedures based upon targeting of the high-powered money base. But increasing liberalization and the progressive opening-up of financial markets made standard transmission mechanisms unstable, and generated a high level of volatility in shortterm money market interest rates. This was one of the major factors provoking a shift back in monetary control procedures towards controlling short-term interest rates during the eighties ${ }^{1}$.

The desire to achieve a high degree of stability in short-term interest rates is also apparent in the discussion, currently underway among national central banks, regarding the operations and procedures to be followed by the European System of Central Banks (ESCB) come Stage Three of Economic and Monetary Union (EMU). But despite some evidence of convergence, significant national differences remain in the institutional mechanics of monetary policy operation across the Community ${ }^{2}$.

One of the areas of less consensus is that regarding the appropriate use of reserve requirements as an instrument of monetary control ${ }^{3}$. One important rationale which has risen to prominence when justifying reserve requirements is their potential stabilising effect on money

\footnotetext{
${ }^{1}$ See, e.g. Kneeshaw and Van den Bergh (1989) and Goodhart (1989).

${ }^{2}$ For recent surveys of monetary policy operations among industrialised countries see, inter alia, Kasman (1992), Bernanke and Mishkin (1992), Schnadt (1993), Economic Unit (1992).

3 Although reserve requirements have in general been lowered in the recent past - both across the Community and elsewhere - significant national differences remain: as a proportion of eligible liabilities, required reserves varied between a high of over 128 in Germany on sigth deposits, and a low of 08 in the United Kingdom, in 1992.
} 
market interest rates. Arguments defending this stabilising effect are based on the notion of reserve requirements as a "buffer-stock" of liquidity. In simple terms, the argument runs as follows: Required reserves need only be met on average over the maintenance period. They can therefore be drawn down to meet any adverse liquidity shock during this period, to be augmented subsequently. This buffer of liquidity, it is argued, thereby insulates the interbank market from such liquidity shocks. Accordingly, money market interest rates - in particular at short maturity - are stabilised.

Both the monetary policy shift towards the use of short-term interest rates during the eighties, and the current debate over the stabilizing effects of reserve requirements, illustrate the importance attributed by most central banks to maintaining stable prices in the very short-term money markets. Hence, implicitly, it is assumed that volatility is not internalised in the short-term money markets, but is instead transmitted, to a significant extent, to the longer term rates relevant to investment and consumption decisions. To our knowledge, however, there is little empirical evidence documenting such strong volatility transmission along the yield curve.

In this paper we consider the empirical basis for the above view. Specifically, we look to model the volatility of money market interest rates - and the transmission of volatility - along the money market yield curve in four European countries: the UK ( $a$ "low" required reserves country); Germany (a "high" required reserves country); and France and Spain (which hold intermediate positions.)

The paper is planned as follows. Section II outlines the methodology used; Section III discusses the measurement of shortest maturity overnight interest rate volatilities. Section IV explores the possibility of volatility transmission along the money market yield curve. And section $\mathbf{V}$ briefly concludes.

\section{METHODOLOGY}

The hypotheses put forward in the introduction are clearly concerned 
primarily with the volatility of money market interest rate movements. Methodologically, a number of approaches have been suggested to model the second-order moments of economic time-series.

The simplest, and least satisfactory, is to take unconditional moments . This is broadly the approach followed in Kasman (1992) when considering some of the issues posed above. Its principal drawback is an economic one: it is uncertainty - the unpredictable part of a variable's movement - rather than variability per se which matters most to economic agents. In particular, when conducting analysis of interbank interest rate behaviour, we would wish to partial out from variance those movements directly attributable to observable official interest rate changes. Such official rate changes are clearly within the information set of agents. Thus, when comparing volatilities over time or across country, we need to control for the differential sizes, speeds and frequencies at which official rates are adjusted.

The above considerations lead us to consider conditional measures of variance. In that regard, various methodologies suggest themselves (see, for example, Pagan and Ullah (1988)). But undoubtedly the most popular in financial economics has been the ARCH approach and subsequent derivatives of it, owing originally to Engle (1983). Here we use a conditional variance specification which is based on Nelson's (1991) Exponential ARCH. This specification allows us to deal with asymmetric responses of conditional variances to negative and positive shocks, and to include exogenous variables in a rather unrestricted way. Thus, given a variable $x_{t}$, we model its conditional variance at period $t-1\left(h_{t}\right)$ as

$$
h_{t}=\exp \left(\omega_{0}+\sum_{1=1}^{p} \omega_{1}\left|\epsilon_{t-1}\right|+\sum_{1=1}^{p^{\prime}} \bar{\omega}_{1} \epsilon_{t-1}+\delta^{\prime} z_{t}\right)
$$

4 See Bollerslev, Chou and Kroner (1992) for a survey of the burgeoning ARCH literature. 
where $\epsilon_{t}\left(=X_{t}-E_{t-1} X_{t}\right)$, is the unexpected component of $X_{t}$ and $Z_{t}$ is a vector of explanatory variables. If $\overline{\omega_{1}}$ is greater (lower) than zero, then the response of the conditional variance to a positive shock at period $t-i$ is larger (lower) than the response to a negative shock ${ }^{5}$.

The log-linear form means that we do not have to restrict the coefficients in the conditional variance specification to be non-negative such as to ensure a non-negative variance. This is important because we want to estimate freely whether it is volatility transmission or volatility transfer which occurs along the money market yield curve.

As we will see below, the term $z_{t}$ typically includes "seasonal" dummies for the overnight interest rate, together with terms that capture volatility transmission effects for longer maturity interest rates. The conditional mean specification accommodates both the steadystate and the dynamic properties of interbank interest rates, with respect to movements in official interest rates.

The conditional variance process together with a conditional mean specification for each maturity interest rate were then jointly estimated using maximum likelihood ${ }^{6}$.

\section{THE CONDITIONAL VARIANCE OF OVERNIGHT INTEREST RATES}

The countries whose money market interest rates we consider are: the UK, Germany, France and Spain. Our sample covers the period January 1988 to January $1993 .^{7}$ The data are daily, thus giving us well over 1000 observations; they come from the Banco de España or from the BIS datatape. Our basic approach to specifying the mean-

${ }^{5}$ The only difference with the specification in Nelson (1991) is that we do not normalize the shocks by their conditional variance.

${ }^{6} \mathrm{~A}$ Gauss code with the estimation routine using analytical derivatives are available from the authors on request.

'In the French case, the sample begins in January 1990. 
variance models is worth briefly touching upon.

Unit root tests, based upon the testing procedure outlined in Perron (1988), indicated that all of the interest rate series - for each country, and at each point along the yield curve - were I(1) processes over our sample. Our general approach was, therefore, to specify our mean model in difference terms, but with an equilibrium solution (errorcorrection mechanism) imposed upon it:

$$
\Delta r_{t}=\alpha_{0}+\alpha_{1}(r-0)_{t-1}+\sum_{1=1}^{m} \beta_{1} \Delta r_{t-1}+\sum_{1=0}^{n} \gamma_{1} \Delta o_{t-1}+\epsilon_{t}
$$

where $\mathbf{r}$ and 0 stand, respectively, for interbank and official interest rates. This mean model can be interpreted as the reduced-form of interactions between official and interbank interest rates.

The levels solution in the mean models is specified such that, in equilibrium, official and money marke: interest rates have a unit relationship. The null of unit cointegration between of ficial and muney market interest rates was not rejected in 14 out of 16 cases; though, predictably, it was weaker the longer the interbank interest rate maturity. Since interest rates are I(1), this cointegration restriction upon money market interest rates is equivalent to imposing meanreversion upon the term premium.

The models for the ( $\log )$ conditional variance were specified as in equation (1). Where appropriate, the autoregressive terms were augmented with asymmetry effects, and with "seasonal" dummies to capture the effects of the reserve requirement maintenance period upon the volatility of interbank interest rates. The dummies accommodate the stylised fact that the variance of interbank interest rates may be heightened towards the end of the reserve maintenance period. Similar such effects have been found to be important in the US, both for the level of interbank interest rates (see Barrett et al. , 1988; Saunders and Urich, 1988) and for their variability (see Spindt and Hoffmeister, 
1988; Lasser, 1988). ${ }^{8}$ Seasonal effects are therefore included here. The specification and interpretation of these mean-variance models for each country can be seen most clearly by considering each in turn.

\section{(a) United Kingdom}

The UK is the most straightforward of the cases to consider since: (i) it has a clearly defined measure of official interest rates to enter into the conditioning set - banks' base rate; ${ }^{9}$ (ii) there is a zero reserve requirement and no reserve maintenance period - hence no reason to expect "seasonal" volatility effects. Our preferred mean-variance specification for UK overnight interest rates is shown in Table 1.

The mean-variance model appears reasonably well-specified: the diagnostics for residual autocorrelation (LM) and ARCH effects (LM2) up to fifth order, are both easily satisfied. Moreover, most parameter values accord with intuition. In the mean model, the impact effect of a 1 percentage point official interest rate change upon overnight rates is 0.58 percentage points. Thereafter, any remaining differential between official and overnight rates is eradicated at the rate $0.23 \%$ per period (the error-correction coefficient). Both parameters are highly significant, and are consistent with reasonably rapid convergence of overnight on official rates - as we would expect from such shortestmaturity interest rates. 908 of the adjustment of overnight rates is completed after 11 days.

The (log) conditional variance model indicates highly significant ARCH effects up to fifth order - justifying our ARCH specification. There are, however, few indications of asymmetries within these effects.

\section{(b) Germany}

${ }^{8}$ We do not, however, find significant seasonal effects on the conditional mean of interbank interest rates for our sample of countries.

'Strictly, the official interest rate of the Bank of England is the dealing rate on shortest maturity (bands 1 and 2) eligible bill purchases. But there is a fixed differential between this rate and base rate over our sample. 
The German case contrasts markedly with the UK one: there is no single, unambiguous measure of official interest rate changes; and the existence of positive reserve requirements means that we might expect maintenance period effects upon conditional variance. This adds to the complexity of the mean-variance specification.

The first problem is the more difficult. The Bundesbank has more than one official rate at its disposal. And these measures are clearly non-orthogonal. Changes in policy may thus be signalled by either the Lombard (ceiling) rate, the Discount (floor) rate, or by the repo rate at the Bundesbank's weekly auction in securities. The first two variables are more of ten used for signalling low frequency shifts in policy, whether when rates are being raised (Lombard), or when they are falling (Discount). The repo rate, by contrast, is more a highfrequency fine-tuning device for, in particular, short-maturity interbank interest rates. But all three may - to greater or lesser extent - potentially influence interbank interest rates along the money market yield curve because of their signalling role.

Our general approach to this problem has been to accommodate all three measures of official rates, freely estimating their dynamic and steady-state relations with money-market interest rates. ${ }^{10}$ Thus the error-correction terms in our German mean models are the residuals from a freely-estimated first-stage levels regression of the interbank interest rate on the three official rates. ${ }^{11}$ It is difficult to give the individual coefficients in this long-run relation a structural interpretation. If there exists more than one cointegrating vector among the variables, these coefficients are a weighted linear combination of each of the structural coefficients. But while interpreting individual coefficients is hazardous, interpreting them collectively is not: taken together, the coefficients define the steadystate relation between interbank interest rates and weighted official rates, where the weights are freely (and superconsistently) estimated.

\footnotetext{
${ }^{10} \mathrm{Using}$ one or other of these rates by itself yielded less satisfactory results; the restrictions imposed seemed not to be satisfied.

${ }^{11}$ As with the other error-correction terms, these re:-1uals were checked for, and found to be, stationary.
} 
Similar logic applies to the dynamic terms in the three official interest rates used in the mean model, which collectively are interpretable as measuring the impact effect of "policy".

On the second problem, the existence of reserve requirements means that we might expect some maintenance period seasonality in the variance of interbank rates. In Germany, the maintenance period runs over one month, ending on the last working day of the month. We accommodate the possibility of seasonality by including two dummy variables: the first accounting for "last day" (of the maintenance period) effects; the other for "last week" effects. Given these considerations, our preferred mean-variance specification for German overnight rates is shown in Table 1.

A number of points are of note. First, the freely estimated coefficients within the error-correction mechanism sum, almost identically, to unity (0.99). This is a desirable property of the system. It means that the German model can be considered the freely-estimated analogue of the other country models (which impose a unit elasticity), only with three measures of official interest rates: there exists steady-state proportionality between overnight and (weighted) official interest rates. The coefficients on the error-correction term $(-0.1)$ and the (sum of the) Lombard and repo rates ${ }^{12}(0.27)$ are both less than half the size of those in the UK case. This suggests a more sluggish convergence of German overnight rates on official rates.

The conditional variance specification, as with the UK, includes $A R C H$ effects up to fifth order, but now with significant asymmetry effects also. The role of the dumny variables within the variance model is particularly striking. They indicate that the conditional variance of German overnight rates is almost two and a half times times greater than its average during the last week of the maintenance period; and more than three and a half times more volatile on the last day of the maintenance period (taking the coefficients on dd and dw together). This finding accords with evidence from the US for the Fed funds rate

\footnotetext{
${ }^{12}$ The Discount rate and the constant term were found to be insignificant and were dropped.
} 
(Spindt and Hoffmeister (1988)). Finally, the German mean-variance model appears reasonably well-specified, with autocorrelation and ARCH tests of the residuals easily satisfied at $5 q$.

\section{(c) France}

The French case has many parallels with the German one. The maintenance period for reserve requirements is again one month; so we include the "last week" and "last day" dummies, as for Germany. But our measure of official rates is simpler than for Germany comprising a single instrument: Mise en Pension (a repo rate). While, in principle, the French system appears similar to the German one with a band of official interest rates, in practice this repo rate was found to serve a dominant signalling function. The error-correction term, then, imposes a unit relationship between overnight rates and this measure of official interest rates. The preferred specification is given in Table 1.

The error-correction coefficient $(-0.19)$ and, in particular, the impact effect of an official rate change ( 0.79$)$ are both significantly larger than in the German case. Convergence of overnight on official rates, following a policy shock, thus occurs rapidly: more than 908 of the adjustment is completed after four days. Within the variance specification, ARCH effects are again significant up to fifth order, and with asymmetries. But the seasonal dummies indicate a much weaker effect upon volatility from the maintenance period than was true for Germany. Conditional variance is only 308 higher than on average on the last day of the maintenance period; and is, if anything, lower than average over the course of the last week. At least part of the explanation for this can be found in the fact that there are carryover provisions for excess reserves under the French system of reserve requirements. These, in turn, serve to diffuse incipient pressures upon liquidity towards the end of the maintenance period. Finally on specification, while there exists some evidence of first-order autocorrelation - the LM test fails at $5 \%$ - there are no signs of remaining $A R C H$ effects within the residuals.

\section{(d) Spain}


The Spanish case is similar to the French one, but for the fact that the maintenance period for reserve requirements runs over a ten-day, rather than one month, period. Accordingly, the seasonal dummies we include cover the last three days of the maintenance period, together with the last day. The Spanish measure of official interest rates is Préstamos de Regulación Monetaria up until 14 May 1990, and thereafter is Subasta de Certificados del Banco de España; both are intervention (repo) rates. The preferred specification is shown in Table 1.

Both diagnostics on the specification are satisfied at 58 . While the impact effect of an official interest rate change is similar to that for the UK, the additional role of the lagged term, together with the errorcorrection coefficient, means that convergence of overnight on official rates is faster than in any of the other three cases: 908 of the adjustment is complete after only two days. The variance model again comprises significant ARCH effects with asymmetries and, most interestingly, accords a large and significant role to the seasonal dummy variables. These dummies indicate that overnight interest rate volatility may be as much as four times higher than its mean on the last day of the maintenance period. This result parallels that found for Germany.

\section{(e) Comparing Overnight Conditional Variances}

Having set down the mean-variance specifications for overnight rates in each country, it remains only to compare our parametric measures of conditional variance across them. Chart 1 summarises the mean values of the overnight interest rate conditional variance for each country. It also gives the required reserve ratio (on sight deposits) as it stood during $1992 .{ }^{13}$

In general, the pattern of overnight volatilities accords with the stabilisation hypothesis. Conditional variability is highest for the zero

\footnotetext{
${ }^{13}$ In France and Germany, required reserve ratios are levied at different rates on different classes of eligible liabilities. Here we have taken sight deposits as our benchmark liability, since these typically comprise a high proportion of banks' total liabilities.
} 
reserve requirement country, the UK; and lowest for the high reserve requirement country, Germany. France and Spain hold intermediate positions: the rankings of their overnight interest rates volatilities is also in line with the levels of required reserves they impose. Naturally, this casual evidence is far from being a formal test of the stabilisation hypothesis. But, despite the countervailing influence of heightened "seasonality" in interbank interest rate volatility, it is consistent with it. On the other hand, this evidence still leaves unresolved the larger question of whether this (in)stability at the short end of the money market yield curve is also evident at the long end: whether excess overnight interest rate volatility translates into longer-term expectations of monetary policy. This is important because not all central banks look to regulate overnight rates as their means of signalling monetary policy changes -for example, in the UK.

\section{VOLATILITY TRANSMISSION}

In this section we consider for each country the mean-variance behaviour of money market rates at one-month, three-month and one year maturities - thereby spanning the whole of the money market yield curve. In addition, given the previous discussion, we consider potential spillovers of volatility from overnight onto longer maturity interest rates; that is, voletility transmission along the money market yield curve. Our general approach to this problem was to substitute into our conditional variance specifications for each maturity interest rate, the measures of overnight interest rate conditional variance generated in section III. The coefficient on this term then measures the proportion of overnight volatility transmitted to longer maturity rates. ${ }^{14}$ Since this proportion need not be independent of the level of gross volatility, we also consider what additional role is played by the maintenance period in the transmission of volatility. For this, we included multiplicative dummies with the overnight conditional variance term, to capture potential additional "last day" and "last week"

\footnotetext{
${ }^{14}$ We assume, conveniently but realistically, that overnight interest rate volatility is not Granger caused by longer maturity interest rate innovations.
} 
volatility transmission. Otherwise, our approach when specifying the mean-variance models was the same as that used in the previous section. The models for each maturity interest rate and for each country are summarised in Tables 2 through 4 . The basic properties of these models are worth briefly summarising.

(a) General Properties of the Mean-Variance Models Along the Yield Curve

The cross-country mean models for different maturity interest rates appear reasonable. Broadly-speaking, the impact effects of policy are smaller, and the rate of convergence on official rates (via the errorcorrection term) is slower, the longer the interest rate maturity. ${ }^{25}$ From an expectations theory perspective, this is a sensible property. On the variance specifications, ARCH effects were again pervasive for each country. Diagnostics on the mean-variance models were in most cases easily satisfied at 58 . Some special cases are, however, worth noting.

First, in the German case the dynamic effect of repo rates upon longer maturity interbank rates was insignificant and thus was omitted. This is consistent with repo rates serving primarily as a fine-tuning device for shortest-maturity interbank rates; they are, correspondingly, less important for longer maturity rates. ${ }^{26}$

Second, for the UK the impact effect of policy is felt as strongly by one and three-month rates as by overnight rates. This is consistent with one to three-month rates being the pivotal point on the UK money market yield curve - the touchstone for agents' expectations of future

\footnotetext{
${ }^{15}$ In the French case, the error-correction term was wrongly signed at a one-year maturity and was omitted. The error-correction coefficient for German one-year rates, though negative, is insignificantly different from zero.

${ }^{16}$ The coefficients in the error-correction term for Germany again sum, proximately, to unity: 0.98 for one month rates; 0.96 for three month rates; and 0.86 for one year rates.
} 
official rates - rather than overnight rates as for other countries.

\section{(b) Comparing Conditional Variances Along the Yield Curve}

Chart 1 summarises our parametric measures of conditional variance for each country along the money market yield curve. This raises a number of points. First, all four countries exhibit a $U$-shaped volatility pattern moving along the yield curve: volatilities are highest at the shortest (overnight) and longest (one year) ends of the curve. Second, volatility clearly falls away more rapidly as we move along the yield curve in the UK than in, for example, Germany. This is consistent with the UK authorities seeking to stabilise money market expectations at a point on the yield curve of longer maturity than one day. Third, despite this, all conditional volatilities along the UK and French money market yield curves lie above those in Germany and Spain. Expectations of monetary policy - as measured along the whole of the money market yield curve - thereby appear noisier in the UK and France.

\section{(c) Volatility Transmission Along the Yield Curve}

There are marked differences in the patterns of volatility transmission cross-country, as measured by the overnight conditional variance parameter and its multiplicative dummies. See Table 5 for a summary of these parameters. The largest differences are those between, on the one hand, Germany and, on the other, the UK, France and Spain.

The UK, French and Spanish cases are the easier to interpret. All three suggest some spillover of volatility from the overnight money market into longer maturity rates. For France and Spain, the extent of this spillover, or volatility transmission, lies between 10-208. This transmission is generally lower, the longer the interest rate maturity again, as we might expect. At all maturities, volatility transmission is significant in France and Spain. In the Spanish case, volatility transmission is proportionally larger on the last day of the maintenance period, when overnight interest rate volatility is up to four times its mean value. Transmission, therefore, appears proportionally greater 
when the level of volatility is high.

These results are consistent with a fairly sizable and robust spillover of uncertainty from the overnight market into longer-term expectations of monetary policy in France and Spain. This transmission goes some way towards explaining why the French and Spanish monetary authorities may seek actively to stabilise overnight interest rates: longer-term monetary policy expectations may be disrupted otherwise.

In the UK, the coefficients measuring volatility transmission - while positive - are in all cases less large than in France and Spain; and for the one month and one year rates, they are in addition statistically insignificant. This lower transmission of volatility is consistent with the UK authorities aiming to stabilise interest rates at a maturity longer than one day, without paying too much attention to reducing overnight interest rate volatility.

But there is an important qualification here. The one point on the UK yield curve where volatility transmission is statistically significant ( 8 o transmission) is at a three-month maturity. This is precisely the point on the UK money market yield curve at which the monetary policy expectations of agents are of ten thought to focus. And, from our estimates, it appears that uncertainty regarding these expectations is not completely insulated from high-frequency noise in the overnight market. Moreover, while volatility transmission is proportionally quite small in the UK, absolute volatility spillovers into longer-term monetary policy expectations are larger than in France or Spain.

The German case is the most perplexing. The signs on the overnight conditional variance terms here are rarely significantly different from zero. Moreover, the one maturity at which volatility effects are significant - one year - they are negatively signed. This suggests transfer, rather than transmission, of volatility along the German money market yield curve ${ }^{17}$.

${ }^{17}$ The (in) significance of the volatility terms is robust to alterations in the variance specification. For example, the inclusion of lags of the overnight conditional variance, or lagged residuals from the overnight 
The nature and significance of volatility transmission seems to be different at the end of the maintenance period. The estimated coefficients for the seasonal dummies suggest that there is a significant transmission effect on the last day of the maintenance period. This last day transmission of volatility appears to be more than counterbalanced, however, by volatility transfers during the remainder of the maintenance period, including during the last week. The net effect of these opposing forces is a poorly determined volatility transmission coefficient.

Explaining the absence of volatility transmission is problematic. One straightforward explanation relies on the existence of non-linearities in the transmission of volatility: only when volatility exceeds some threshold value are its effects reflected elsewhere along the yield curve. The fact that the mean value of overnight interest rate variability was found in section III to be lowest in Germany is consistent with this explanation. And the significance of the seasonal volatility effects - for example in Spain - means that we already have reason to suspect non-linearities: volatility transmission as a proportion of total volatility appears greater, the higher is gross volatility.

But the non-linearity hypothesis hardly suffices to explain the counterintuitive result found for Germany. Taking together the evidence for the UK, France and Spain, the fact that the country with highest interest rate volatility (the UK) is also the country with smallest transmission coefficient, points in a direction contrary to the one predicted by this hypothesis. Further, the inclusion of non-linear terms in the conditional variance specifications did not provide significant, or correctly signed, coefficients in any country.

Another hypothesis that might serve to justify the absence of volatility transmission effects in Germany is that interbank markets at different maturities are somewhat segmented. However, to our knowledge, there is no institutional device that could explain such a feature of the German financial markets. Moreover, our estimated conditional mean equations suggest that the relation between

mean model (proxies for direct "shocks" to the overnight rate). 
intervention and longer term rates is not significantly weaker in Germany than in other countries. This result would be unlikely if German interbank markets of different maturities were segmented.

Taken alongside the evidence from other countries, therefore, the lack of volatility transmission along the German money market yield curve presents a puzzle. Not least this is the case because one of the Bundesbank's declared rationales for wishing to stabilise the overnight rate is precisely to prevent volatility spilling-over into the rest of the money market yield curve: spillovers which - on this evidence - do not appear significant.

Naturally, this evidence is not conclusive enough to criticize the Bundesbank's strategy or to invalidate the justification given to pursue it. To the contrary: our failure to find significant volatility transmission along the yield curve in Germany may be precisely a consequence of its prevailing monetary regime. So our results cannot be used to predict the consequences for money market volatility of relaxing the priority given to stabilising overnight interest rates. Such an exercise would clearly fall foul of the Lucas critique.

\section{v. CONCLUSIONS}

In this paper we have found a significant volatility transmission effect from overnight to longer term money market rates for France, Spain and the UK. This evidence is supportive of the importance attributed by most central banks to achieving a reasonable level of stability in the very short-term money markets. I follows that since overnight interest rate volatility is not completely internalized in that market, it is likely to influence real -saving and investment- decisions.

Although this paper did not provide a direct test of the stabilization hypothesis for reserve requirements, the evidence presented might help to illuminate the debate on that issue. Thus, in our small cross section of countries, we observe that those with lower (higher) reserve requirements tend to have higher (lower) interbank interest rate volatility. Reserve requirements do, however, generate a perverse 
destabilising seasonal effect: at the end of the maintenance period, both the level of overnight interest rate volatility and the magnitude of the transmission effect to the rest of the yield curve are higher.

Finally, we should conclude with an important caveat. In this paper, despite the results for UK, France and Spain, we have not found significant positive volatility transmission effects for Germany. This finding is particularly unexpected considering the Bundesbank's publicly acknowledged interest and success in attaining stability in the short-term money markets. This evidence suggests that the strength of volatility transmission across financial markets may not be independent of the prevailing monetary policy regime and, therefore, that policy makers could be partially responsible for the proportion of short-term volatility that gets transmitted to longer term interest rates. Given its obvious normative implications, the analysis of this hypothesis deserves additional research. 
Table 1

\begin{tabular}{|c|c|c|c|c|}
\hline \multicolumn{5}{|c|}{ INTEREST RATE MATURITY: 1 DAY } \\
\hline \multicolumn{5}{|c|}{$\Delta r_{t}=a_{0}+a_{1}(r-0)_{t-1}+\sum_{i=1}^{m} B_{1} \Delta r_{t-1}+\sum_{1=0}^{n} \gamma_{1} \Delta o_{t-1}+\epsilon_{t} ; \epsilon_{t \mid t-1}-D\left(0, h_{t}\right)$} \\
\hline & FRANCE & GERMANY & SPAIN & U.K. \\
\hline$a_{0}$ & $-0.12(.01)$ & & $4 E-3(3 E-3)$ & $-0.04(.01)$ \\
\hline$a_{1}$ & $-0.19(.01)$ & $-0.10(.01)$ & $-0.10(.01)$ & $-0.24(.02)$ \\
\hline$B_{1}$ & & & & $-0.23(.02)$ \\
\hline$B_{2}$ & & & & $-0.14(.02)$ \\
\hline$B_{3}$ & & & & $-0.07(.02)$ \\
\hline$\gamma_{0}$ & $0.79(.01)$ & $0.27^{(a)}$ & $0.59(.02)$ & $0.58(.07)$ \\
\hline$\gamma_{2}$ & & & $0.27(.03)$ & \\
\hline$\omega_{0}$ & $-0.13(4 E-4)$ & $-0.15(3 E-4)$ & $-0.15(4 E-4)$ & $-0.12(5 E-4)$ \\
\hline$\omega_{2}$ & $0.86(.10)$ & $4.66(.16)$ & $5.74(.20)$ & $0.97(.11)$ \\
\hline$\omega_{2}$ & $3.64(.07)$ & $3.45(.16)$ & $2.78(.08)$ & $1.17(.08)$ \\
\hline $\boldsymbol{\omega}_{3}$ & $0.21(.09)$ & $-0.81(.19)$ & $0.18(.16)$ & $0.20(.09)$ \\
\hline$\omega_{4}$ & $0.21(.10)$ & $1.04(.14)$ & $1.31(.15)$ & $0.76(.09)$ \\
\hline $\boldsymbol{\omega}_{\mathrm{s}}$ & $0.51(.08)$ & $-0.85(.17)$ & & $0.40(.10)$ \\
\hline$\overline{\boldsymbol{\omega}}_{1}$ & $0.33(.10)$ & $-2.43(.15)$ & $-0.84(.15)$ & \\
\hline $6_{2}$ & $-0.27(.06)$ & $1.41(.05)$ & $0.35(.06)$ & \\
\hline $6_{3}$ & $0.52(.14)$ & $1.23(.10)$ & $2.61(.06)$ & \\
\hline LM & 15.47 & 9.52 & 9.83 & 8.86 \\
\hline LM2 & 8.11 & 5.48 & 10.46 & 4.60 \\
\hline
\end{tabular}

(a) $.39(.02)$ and -.12 (.03) for Lombard and Repo rates, respectively.

- o stands for official intervention interest rate. $0=-0.05$ Discount +0.20 Lombard + 0.84 Repo for Germany.

- Standard errors in parenthesis.

- $\omega$ and $\bar{\omega}$ parameters are divided by $10^{2} . a_{0}$ is multiplied by $10^{2}$.

- LM and LM2 are Lagrange tests for residual autocorrelation and residual conditional heteroscedasticity; respectively, both up to order five. 
Table 2

\begin{tabular}{|c|c|c|c|c|}
\hline \multicolumn{5}{|c|}{ INTEREST RATE MATURITY: 1 MONTH } \\
\hline \multicolumn{5}{|c|}{$\begin{aligned} \Delta r_{t} & =a_{0}+a_{1}(r-0)_{t-1}+\sum_{1=1}^{D} B_{1} \Delta r_{t-1}+\sum_{1=0}^{D} \gamma_{1} \Delta o_{t-1}+\epsilon_{\tau} ; \epsilon_{\tau \mid c-1}-D\left(0, h_{t}\right) \\
\log h_{t} & =\omega_{0}+\sum_{1=1}^{p} \omega_{1}\left|\epsilon_{t-1}\right|+\sum_{1=1}^{p} \bar{\omega}_{1} \epsilon_{t-1}+\delta_{1} \log h_{t}^{1 D}+\delta_{2}\left(\log h_{t}^{1 D} \cdot d w_{t}\right)+\delta_{3}\left(\log h_{t}^{1 D} \cdot d d_{t}\right)\end{aligned}$} \\
\hline & FRANCE & GERMANY & SPAIN & U.K. \\
\hline$a_{0}$ & $-0.02(3 E-3)$ & & $0.01(2 \mathrm{E}-3)$ & $-0.01(2 \mathrm{E}-3)$ \\
\hline$a_{1}$ & $-0.03(.01)$ & $-0.03(.01)$ & $-0.04(2 E-3)$ & $-0.22(.01)$ \\
\hline$B_{1}$ & & & $0.26(.02)$ & \\
\hline $\boldsymbol{\gamma}_{0}$ & $0.10(.04)$ & $0.22^{(\bullet)}$ & $0.37(.01)$ & $0.55(.01)$ \\
\hline$\gamma_{1}$ & $0.12(.02)$ & & $0.11(.03)$ & \\
\hline$\gamma_{s}$ & $0.16(.03)$ & & & \\
\hline$\omega_{0}$ & $-0.13(3 E-3)$ & $-0.16(4 E-3)$ & $-0.13(4 E-4)$ & $-0.14(3 E-3)$ \\
\hline$\omega_{1}$ & $2.36(.18)$ & $6.13(.42)$ & $9.38(.35)$ & $3.74(.30)$ \\
\hline$\omega_{2}$ & $1.26(.16)$ & $5.57(.36)$ & $4.14(.43)$ & $1.36(.28)$ \\
\hline$\omega_{3}$ & $2.11(.16)$ & $2.74(.41)$ & $0.84(.38)$ & $2.26(.17)$ \\
\hline$\omega_{4}$ & $2.86(.21)$ & $3.93(.41)$ & $3.13(.49)$ & \\
\hline$\omega_{5}$ & $2.15(.24)$ & $-1.22(.55)$ & & \\
\hline $\bar{\omega}_{1}$ & & $2.94(.30)$ & $3.74(.28)$ & $0.54(.23)$ \\
\hline $\bar{\omega}_{2}$ & & & $3.09(.32)$ & \\
\hline$\delta_{1}$ & $0.12(.02)$ & $-0.01(.03)$ & $0.20(.02)$ & $0.02(.02)$ \\
\hline$\delta_{2}$ & $0.07(.01)$ & $-0.04(.01)$ & $4 E-4(4 E-3)$ & \\
\hline$\delta_{3}$ & $0.01(.01)$ & $0.06(.01)$ & $0.02(.01)$ & \\
\hline LM & 5.45 & 5.26 & 17.48 & 6.93 \\
\hline LM2 & 3.97 & 5.05 & 2.51 & 0.98 \\
\hline
\end{tabular}

(a) .32 (.02) and -.10 (.03) for Lombard and Discount rates, respectively.

- o stands for official intervention interest rate. $o=-.19$ Discount +.19 Lombard +.98 Repo for Germany.

- Standard errors in parenthesis.

- $\omega$ and $\bar{\omega}$ parameters are divided by $10^{2}, a_{0}$ is multiplied by $10^{2}$.

- LM and LM2 are Lagrange tests for residual autocorrelation and residual conditional heteroscedasticity, respectively, both up to order five. 
Table 3

\begin{tabular}{|c|c|c|c|c|}
\hline \multicolumn{5}{|c|}{ INTEREST RATE MATURITY: 3 MONTHS } \\
\hline \multicolumn{5}{|c|}{$\begin{aligned} \Delta r_{t} & =a_{0}+a_{1}(r-0)_{t-1}+\sum_{i=1}^{\infty} B_{1} \Delta r_{t-1}+\sum_{1=0}^{D} \gamma_{1} \Delta o_{t-1}+\epsilon_{t} ; \epsilon_{t \mid t-1}-D\left(0, h_{t}\right) \\
\log h_{t} & =\omega_{0}+\sum_{1=1}^{p} \omega_{1}\left|\epsilon_{t-1}\right|+\sum_{t=1}^{p} \bar{\omega}_{1} \epsilon_{t-1}+\delta_{1} \log h_{t}^{2 D}+\sigma_{2}\left(\log h_{t}^{10} \cdot d w_{t}\right)+\sigma_{3}\left(\log h_{t}^{10} \cdot d d_{t}\right)\end{aligned}$} \\
\hline & FRANCE & GERMANY & SPAIN & U.K. \\
\hline$\alpha_{0}$ & $-0.03(2 E-3)$ & & $5 E-3(3 E-3)$ & $-6 E-3(3 E-3)$ \\
\hline$a_{1}$ & $-0.05(4 \mathrm{E}-3)$ & $-0.02(5 E-3)$ & $-0.02(3 E-3)$ & $-0.07(.01)$ \\
\hline$B_{1}$ & & & $0.19(.02)$ & $-0.05(.02)$ \\
\hline$Y_{0}$ & $0.17(.01)$ & $0.13^{(a)}$ & $0.26(.01)$ & $0.61(.01)$ \\
\hline$Y_{1}$ & $0.17(.01)$ & & $0.17(.02)$ & \\
\hline$\gamma_{s}$ & $0.15(.02)$ & & & \\
\hline$\omega_{0}$ & $-0.13(3 E-3)$ & $-0.16(4 \mathrm{E}-3)$ & $-0.14(2 E-3)$ & $-0.14(4 E-3)$ \\
\hline$\omega_{1}$ & $3.10(.24)$ & $7.49(.48)$ & $6.88(.48)$ & $4.12(.36)$ \\
\hline$\omega_{2}$ & $2.55(.31)$ & $6.41(.38)$ & $5.87(.40)$ & $0.99(.38)$ \\
\hline$\omega_{3}$ & $2.85(.30)$ & $2.47(.42)$ & $-1.39(.45)$ & $3.08(.38)$ \\
\hline$\omega_{4}$ & $0.74(.29)$ & $2.54(.49)$ & $3.23(.56)$ & $-0.11(.35)$ \\
\hline$\omega_{5}$ & $2.39(.21)$ & & & $1.57(.40)$ \\
\hline $\bar{\omega}_{1}$ & $-0.78(.17)$ & $1.37(.35)$ & $-0.76(.38)$ & \\
\hline$\overline{\boldsymbol{\omega}}_{2}$ & & & $1.46(.30)$ & \\
\hline$\delta_{1}$ & $0.12(.02)$ & $-0.03(.03)$ & $0.11(.01)$ & $0.08(.03)$ \\
\hline $6_{2}$ & $0.03(5 E-3)$ & $-3 E-3(5 E-3)$ & $-7 E-3(4 E-3)$ & \\
\hline$\delta_{3}$ & $-2 \mathrm{E}-3(.01)$ & $0.02(.01)$ & $0.04(.01)$ & \\
\hline LM & 7.33 & 9.58 & 13.92 & 8.75 \\
\hline LM2 & 1.63 & 5.44 & 3.49 & 3.69 \\
\hline
\end{tabular}

(a) $.31(.01)$ and -.18 (.02) for Lombard and Discount rates, respectively.

- o stands for official intervention interest rate. $o=-0.37$ Discount +0.23 Lombard + 1.10 Repo for Germany.

- Standard errors in parenthesis.

- $\omega$ and $\bar{\omega}$ parameters are divided by $10^{2} . \alpha_{0}$ is multiplied by $10^{2}$.

- LM and LM2 are Lagrange tests for residual autocorrelation and residual conditional heteroscedasticity, respectively, both up to order five. 


\begin{tabular}{|c|c|c|c|c|}
\hline \multicolumn{5}{|c|}{ INTEREST RATE MATURITY: 1 YEAR } \\
\hline \multicolumn{5}{|c|}{$\begin{aligned} \Delta r_{t} & =a_{0}+a_{1}(r-0)_{t-1}+\sum_{1=1}^{D} B_{1} \Delta r_{t-1}+\sum_{1=0}^{n} \gamma_{1} \Delta o_{t-1}+\epsilon_{t} ; \epsilon_{t / t-1}-D\left(0, h_{t}\right) \\
\log h_{\tau} & =\omega_{0}+\sum_{1=1}^{p} \omega_{1}\left|\epsilon_{t-1}\right|+\sum_{1=1}^{p} \bar{\omega}_{1} \epsilon_{t-1}+\delta_{1} \log h_{\tau}^{1 D}+\delta_{2}\left(\log h_{t}^{1 D} \cdot d w_{t}\right)+\delta_{3}\left(\log h_{t}^{10} \cdot d d_{t}\right)\end{aligned}$} \\
\hline & FRANCE & GERMANY & SPAIN & U.K. \\
\hline$\alpha_{0}$ & & & $8 E-3(2 E-3)$ & $-5 E-3(2 E-3)$ \\
\hline$\alpha_{1}$ & & $-6 E-3(.33)$ & $-0.01(2 E-3)$ & $-0.01(4 \mathrm{E}-3)$ \\
\hline$B_{1}$ & $-0.06(.02)$ & & & \\
\hline $\mathrm{B}_{2}$ & $-0.18(.02)$ & & & \\
\hline$\gamma_{0}$ & $0.02(.02)$ & $0.02^{(\Delta)}$ & $0.25(.01)$ & $0.27(.01)$ \\
\hline $\boldsymbol{r}_{1}$ & & & $0.29(.01)$ & \\
\hline$\gamma_{s}$ & $0.05(.04)$ & & & \\
\hline$\omega_{0}$ & $-0.13(2 E-3)$ & $-0.16(2 E-3)$ & $-0.14(2 E-3)$ & $-0.14(3 E-3)$ \\
\hline$\omega_{1}$ & $0.67(.28)$ & $5.55(.32)$ & $3.18(.29)$ & $4.00(.27)$ \\
\hline$\omega_{2}$ & $1.52(.13)$ & $3.85(.24)$ & $4.65(.31)$ & $0.92(.36)$ \\
\hline$\omega_{3}$ & $3.36(.39)$ & $3.64(.37)$ & $3.28(.37)$ & $1.17(.25)$ \\
\hline$\omega_{4}$ & $2.12(.35)$ & $4.18(.44)$ & $2.63(.34)$ & $1.46(.30)$ \\
\hline$\omega_{s}$ & $1.41(.15)$ & & & \\
\hline $\bar{\omega}_{1}$ & $-0.89(.25)$ & $1.37(.35)$ & & \\
\hline$\delta_{1}$ & $0.08(.02)$ & $-0.04(.02)$ & $0.10(.02)$ & $0.03(.03)$ \\
\hline$\delta_{2}$ & $0.06(.01)$ & $0.03(4 E-3)$ & $0.45(.05)$ & \\
\hline$\delta_{3}$ & $0.04(.01)$ & $1 \mathrm{E}-3(.01)$ & $0.05(.01)$ & \\
\hline$L M$ & 9.40 & 7.19 & 7.21 & 4.75 \\
\hline LM2 & 1.91 & 10.67 & 5.19 & 0.90 \\
\hline
\end{tabular}

(a) .18 (.02) and $-.17(.04)$ for Lombard and Discount rates, respectively.

- o stands for official intervention interest rate. $0=-.90$ Discount +.35 Lombard +1.41 Repo for Germany.

- Standard errors in parenthesis.

$-\omega$ and $\bar{\omega}$ parameters are divided by $10^{2}, a_{0}$ is multiplied by $10^{2}$.

- LM and LM2 are Lagrange tests for residual autocorrelation and residual conditional heteroscedasticity, respectively, both up to order five. 
Table 5 .

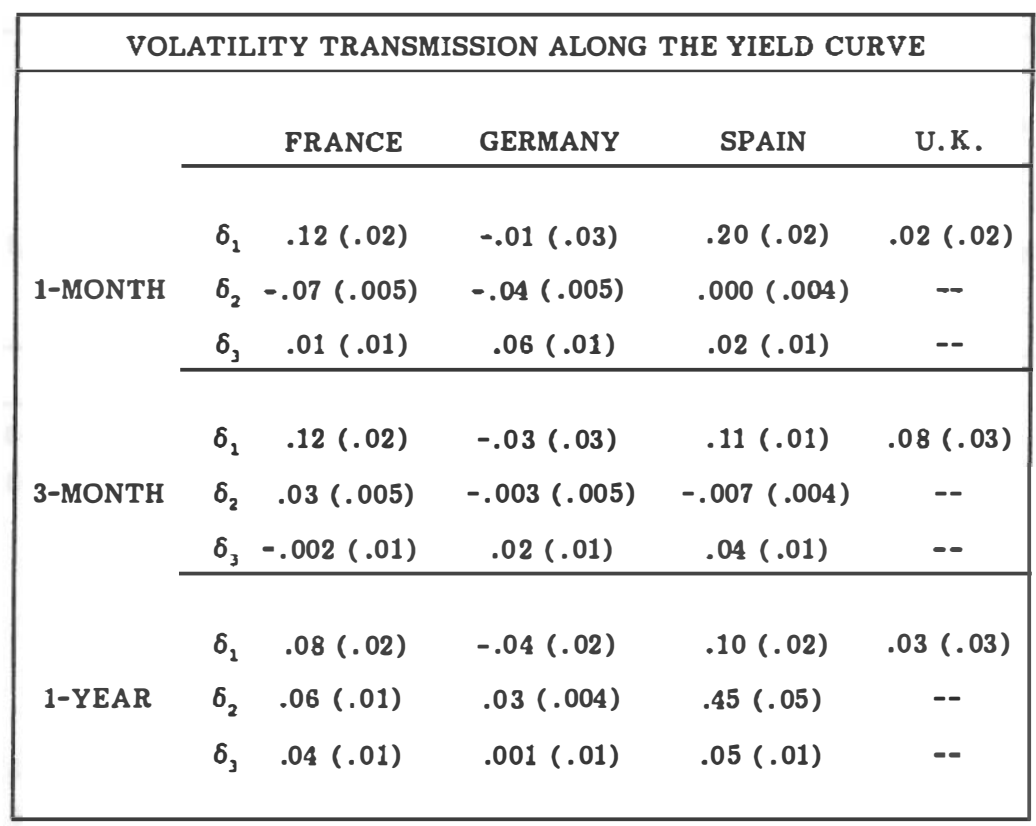

- $\delta_{1}, \delta_{2}$, and $\delta_{3}$ are the coefficients of overnight interest rate (log) conditional variance, 'last week additional effect' dummy and 'last day additional effect' dummy, respectively.

- Standard errors in parenthesis. 
Chart 1

MEANS OF (LOG) CONDITIONAL VARIANCES FOR MONEY MARKET INTEREST RATES

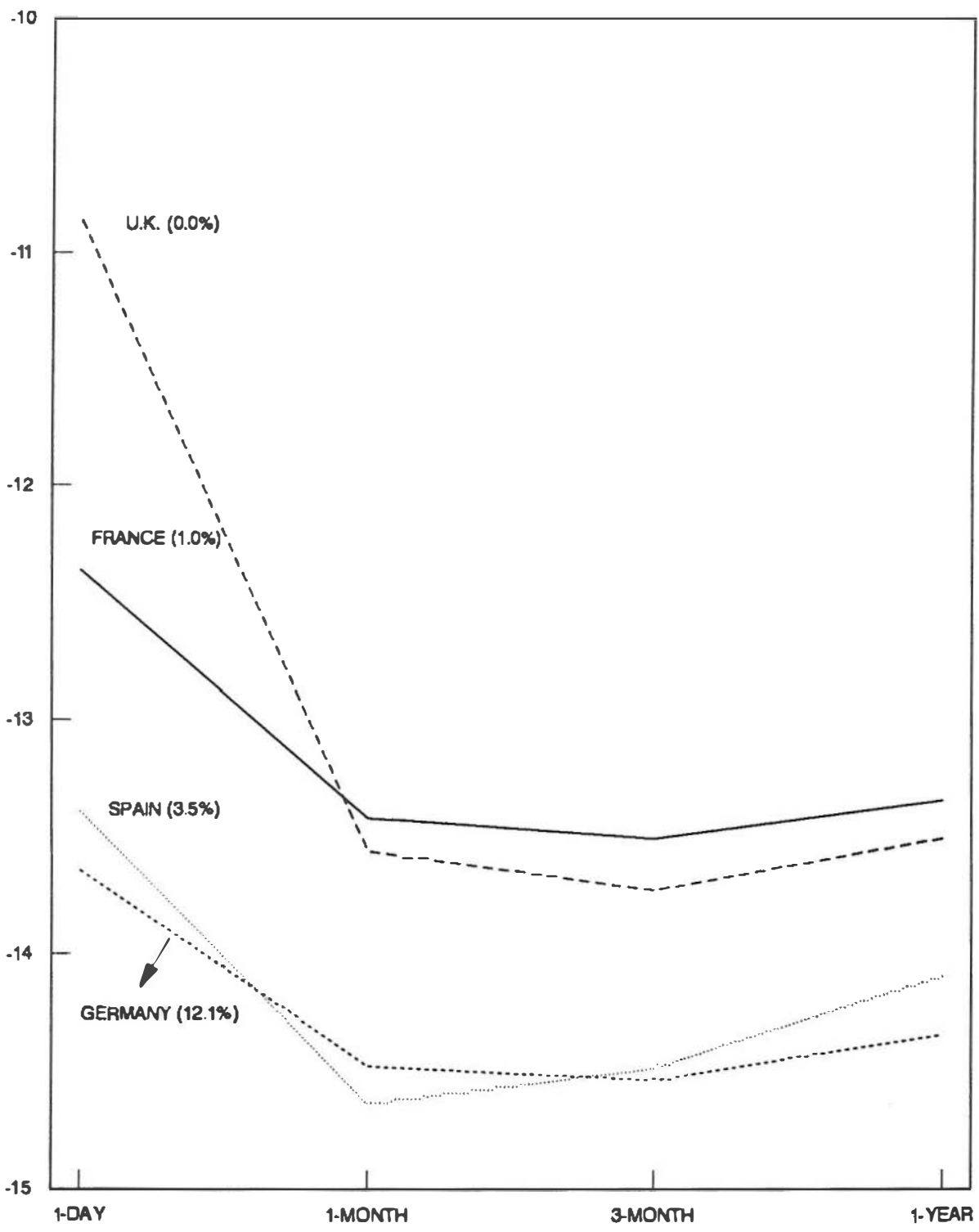

NOTE: In parenthesis, required Reserve Ratio on Sight Deposits as at 1992.

$$
-27 \text { - }
$$





\section{References}

Barrett, W B, Slovin, M B, and M E Sushka (1988), 'Reserve Regulation as a Source of Risk Premia in the Federal Funds Market', Journal of Banking and Finance, 12, 575-584.

Bernanke, B S and F Mishkin (1992), 'Central Bank Behaviour and the Strategy of Monetary Policy: Observations from Six Industrialised Countries', NBER Working Paper \#4082.

Bollerslev, T, Chou, R Y and K F Kroner (1992), 'ARCH Modelling in Finance', Journal of Econometrics, 52, 5-59.

Economic Unit of the Committee of Governors of the Central Banks of the Member States of the EEC (1992), 'A Framework to Assess Monetary Policy Instruments and Procedures in EC Countries'.

Engle, R F (1983), 'Autoregressive Conditional Heteroskedasticity with Estimates of the Variance of UK Inflation', Econometrica, 50, 987-1008.

Goodhart, C A E (1989), 'The Conduct of Monetary policy', Economic Journal, 99, 293-346.

Kasman, B (1992), 'A Comparison of Monetary Policy Operating Procedures in Six Industrial Countries', Federal Reserve Bank of New York, Quarterly Review, 5-24.

Kneeshaw, J T and P Van den Bergh (1989), 'Changes in Central Bank Money Market Operating Procedures in the 1980s', BIS Economic Papers.

Lasser, D J (1992), 'The Effect of Contemporaneous Reserve Accounting on the Market for Federal Funds', Journal of Banking and Finance, 16, 1047-56. 
Nelson, D B (1991), 'Conditional Heteroskedasticity in Asset Returns: A New Approach', Econometrica, 59, 347-370.

Pagan, A R and A Ullah (1988), 'The Econometric Analysis of Models with Risk Terms', Journal of Applied Econometrics, 3, 87-105.

Perron, P (1988), 'Trends and Random Walks in Macroeconomic Time Series', Journal of Economic Dynamics and Control, 12, 297-\$32.

Saunders, A and T Urich (1988), 'The Effects of Shifts in Monetary Policy and Reserve Accounting Regimes on Bank Reserve Management in the Federal Funds Market', Journal of Banking and Finance, 11, 52336 .

Schnadt, N (1993), 'Domestic Money Markets: France, Germany and the United States', mimeo, LSE.

Spindt P A and J R Hoffmeister (1988), 'The Micromechanics of the Federal Funds Market: Implications for day-of-the-week effects in Funds Rate Variability', Journal of Financial and Quantitative Analysis, 23, 401-416. 


\section{WORKING PAPERS (1)}

930I Emiliano González Mota: Políticas de estabilización y límites a la autonomía fiscal en un área monetaria y económica común.

9302 Anindya Baner jee, Juan J. Dolado and Ricardo Mestre: On some simple tests for cointegration: the cost of simplicity.

9303 Juan Ayuso and Juan Luis Vega: Weighted monetary aggregates: The Spanish case. (The Spanish original of this publication has the same number.)

9304 Ángel Luis Gómez Jiménez: Indicadores de la política fiscal: una aplicación al caso español.

9305 Ángel Estrada y Miguel Sebastián: Una serie de gasto en bienes de consumo duradero.

9306 Jesús Briones, Ángel Estrada e Ignacio Hernando: Evaluación de los efectos de reformas en la imposición indirecta

9307 Juan Ayuso, María Pérez Jurado and Fermando Restoy: Credibility indicators of an exchange rate regime: the case of the peseta in the EMS. (The Spanish original of this publication has the same number.)

9308 Cristina Mazón: Regularidades empíricas de las empresas industriales españolas: ¿,existe correlación entre beneficios y participación?

9309 Juan Dolado, Alessandra Goria and Andrea Ichino: Immigration and growth in the host country.

9310 Amparo Ricardo Ricardo: Series históricas de contabilidad nacional y mercado de trabajo para IaCE y EEUU: 1960-1991.

931] Fernando Restoy and G. Michael Rockinger: On stock market returns and returns on investment.

9312 Jesús Saurina Salas: Indicadores de solvencia bancaria y contabilidad a valor de mercado.

9313 Isabel Argimón, José Manuel González-Páramo, María Jesús Martín y José María Roldán: Productivity and infrastructure in the Spanish economy. (The Spanish original of this publication has the same number.)

9314 Fernando Ballabriga, Miguel Sebastián and Javier Vallés: Interdependence of EC economies: A VAR approach.

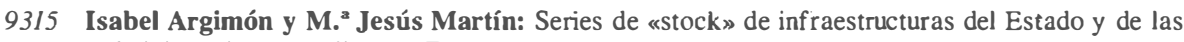
Administraciones Públicas en España.

9316 Pedro Martínez Méndez: Fiscalidad, tipos de interés y tipo de cambio.

9317 Pedro Martínez Méndez: Efectos sobre la política económica española de una fiscalidad distorsionada por la inflación.

9318 Pablo Antolín and Olympia Bover: Regional Migration in Spain: The effect of Personal Characteristics and of Unemployment, Wage and House Price Differentials Using Pooled Cross-Sections.

9319 Samuel Bentolila y Juan J. Dolado: La contratación temporal y sus efectos sobre la competitividad.

9320 Luis Julián Álvarez, Javier Jareño y Miguel Sebastián: Salarios públicos, salarios privados e inflación dual.

9321 Ana Revenga: Credibility and inflation persistence in the European Monetary System. (The Spanish original of this publication has the same number.)

9322 María Pérez Jurado and Juan Luis Vega: Purchasing power parity: An empirical analysis. (The Spanish original of this publication has the same number.)

9323 Ignacio Hernando y Javier Vallés: Productividad sectorial: comportamiento cíclico en la economía española.

9324 Juan J. Dolado, Miguel Sebastián and Javier Vallés: Cyclical patterns of the Spanish economy.

9325 Juan Ayuso y José Luis Escrivá: La evolución del control monetario en España.

9326 Alberto Cabrero Bravo e Isabel Sánchez García: Métodos de predicción de los agregados monetarios. 
9327 Cristina Mazón: Is profitability related to market share? An intra-indusıy study in Spanish manufacturing.

9328 Esther Gordo y Pilar L'Hotellerie: La competitividad de la industria española en una perspectiva macroeconómica.

9329 Ana Buisán y Esther Gordo: El saldo comercial no energético español: determinantes y análisis de simulación (1964-1992).

9330 Miguel Pellicer: Functions of the Banco de España: An historical perspective.

9401 Carlos @caña, Vicente Salas y Javier Vallés: Un análisis empírico de la tĩnanciación de la pequeña y mediana empresa manufacturera española: 1983-1989.

9402 P. G. Fisher and J. L. Vega: An empirical analysis of M4 in the United Kingdom.

9403 J. Ayuso, A. G. Haldane and F. Restoy: Volatility transmission along the money market yield curve.

(1) Working Papers prior t 1993 are listed in Banco de España's publications catalogue.

Queries should be addressed to: Banco de España

Sección de Publicaciones. Negociado de Distribución y Gestión

Teléfono: 3385180

Alcalá, 50. 28014 Madrid 